\title{
Role of Intellectual Capital on the Organizational Performance of Electrical and Electronic SMEs in Pakistan
}

\author{
Muhammad Khalique (Corresponding author) \\ PhD Student, Faculty of Economics and Business, Universiti Malaysia Sarawak \\ Sarawak, Malaysia \\ E-mail: cks748@gmail.com \\ Dr. Jamal Abdul Nassir Shaari \\ Senior Lecturer, Faculty of Economics and Business, Universiti Malaysia Sarawak \\ Sarawak, Malaysia \\ Professor Dr Abu Hassan Md. Isa \\ Head Department of Accounting and Finance, Faculty of Economics and Business \\ Universiti Malaysia Sarawak, Sarawak, Malaysia \\ Adel Ageel \\ PhD Student, Faculty of Economics and Business, Universiti Malaysia Sarawak \\ Sarawak, Malaysia \\ E-mail: adel_ali665@yahoo.com
}

Received: March 15, 2011 Accepted: April 14, 2011 doi:10.5539/ijbm.v6n9p253

\begin{abstract}
Intellectual capital is a prime strategic asset for organizations in a knowledge based economy. In a knowledge based economy it is indispensible for organizations to indentify, maximize and utilize their intellectual capital to stay in a competitive environment. The main crux of this paper is to examine the relationship of intellectual capital with organizational performance of electrical and electronics SMEs operating in manufacturing sector in Pakistan. This research is conducted in two cities of "Golden Tri Angle" namely Gujrat and Gujranwala in Pakistan. Convenience sampling technique was used for data collection. Structured questionnaires were administrated as a research instrument to collect data from respondents. Pearson Correlation and Multiple Regression were used to test the relationship between components of intellectual capital and organizational performance. This is the first study that focused on small and medium enterprises in Pakistan to examine the relationship of intellectual capital with organizational performance.

Keywords: Human capital, Customer capital, Structural capital, Intellectual capital, Organizational performance

\section{Introduction}

The contribution of small and medium enterprises (SMEs) to economic development in developed and underdeveloped economies has been highly acknowledged. In present era many countries support SMEs development due to their positive contribution to sustain broad and diversified private sector in job creation, income generation, and uplifting life style and reduction of poverty (UNIDO, 2002). According to UNINDO (2000), more than $90 \%$ of worldwide businesses is SMEs', providing 50 to 60 percent employment.

Similar to other developing countries, Pakistan economy is mainly based on SMEs worth 3.2 million a more than 99 percent of the total businesses (Kureshi et al., 2009; Rohra and Panhwar, 2009). Pakistan economy is considered as agriculture based besides other sectors such as service and manufacturing sector also playing important roles. Manufacturing sector is the second largest sector of national economy accounted for $23 \%$ of Pakistan's GDP in 2005-2006 (Federal Bureau of Statistics, 2005-06); making it one of the prime strategic functions of business with significant contribution (Yusuff, 2004; Terziovski, 2010). Alam (2009) argues that
\end{abstract}


Pakistan's manufacturing sector can be divided into two sectors that are large scale manufacturing units and small scale manufacturing units.

Electrical and electronics SMEs operating in manufacturing sector are considered as high tech industries. The role of electrical and electronics (E\&E) SMEs in Pakistan particularly in small scale manufacturing sector is very important and has major contribution to national economy. 65\% of these SMEs are based in Punjab Province with Gujranwala, Gujrat and Sialkot known as Golden Tri-Angle cities due to more than $60 \%$ of E\&E SMEs are based in these three cities. This research is focused on Gujranwala and Gujrat cities due to them being famous for electrical and electronics SMEs (SMEDA Report, 2007-2008).

\subsection{Definition of SMEs}

There is no uniform definition of SME available as it varies from country to country. The definition of SMEs is mainly based on three attributes, namely number of employees, paid-up capital and annual revenues. The definition of SMEs in Pakistan also lies on the above mentioned attributes: number of employees up to 250 people, paid-up capital up to Rs.25 million and annual sales up to Rs.250 million (Kureshi et al., 2009)

Man et al., (2002) argues that success of SMEs is influenced by knowledge, experience and skills of the owners and employees. The major strength of SMEs exist in innovation, good network, unique skills, rapid communication, less bureaucracy, close contact to market and internally, etc. which is important for innovation and success (Nooteboom, 1993). Most of the research studies highlighted that SMEs has faced lack of tangible resources such as physical and financial capital; thus in this knowledge based economy the challenge for the SMEs is to utilize their intangible resources, their intellectual capital embedded in their organization (Erikson, 2002). SMEs need to be more aware of the importance and applications of intellectual capital. Intellectual capital has becomes an important determinant of competitive advantages (Chen et al., 2006).

\section{Literature Review}

There are large numbers of definition of intellectual capital available in literature. (According to Stewart (1994) intellectual capital is defined as the total stock of the collective knowledge, information, technologies, skills, expertise, intellectual property, team management and customer satisfaction that can be used to create organization wealth. Bontis et al., (2000) explained intellectual capital as submission of individual workers' and organizational knowledge that contribute to sustainable competitive advantage. Cabrita (2009) argue that there is a consensus that intellectual capital is a set of intangible resources such as capabilities, skills, and competences that drive the organizational performance and value creation (Roos and Roos, 1997; Bontis, 1998). Researchers concluded that intellectual capital is a major source for organization to gain competitive advantages in knowledge based economy; (Chen and Lin, 2004 Stewart, 1997; Wall et al. 2004; Cabrita, 2009; Shaari et al., 2010). Stewart (1997) and Bontis et al., (2000) categorized intellectual capital into human capital, customer capital and structural capital.

\subsection{Human Capital}

According to Ding and Li (2010) human capital includes various skills, knowledge and abilities possessed by employees for the sustainable development of the enterprises. Human capital is recognized as a main component of intellectual capital (Edvinsson and Malone, 1997; Stewart, 1997; Bontis, 1998; Choo and Bontis, 2002; Shaari, et al., 2010). According to Bontis (1998) at the organizational level, human capital is considered as a source of innovation and strategic renewal. Roos and Roos (1997) and Shaari et al., (2010) stated that successful creation of intellectual capital are mainly based on the competences, attitude and intellectual agility of employees in an organization. Therefore human capital is the fundamental source of organization to create wealth.

\subsection{Customer Capital}

According to Bontis (1998) customer capital is defined as the knowledge embedded in the marketing channels and customer relationships. Customer capital is also one of the most important components of intellectual capital. Customer capital mainly based on marketing capability, customer loyalty, and relationship with customer and customer satisfactions (Amiri et al., 2010).

\subsection{Structural Capital}

Structural capital is another important ingredient for the success of organizations. It can be considered as those capabilities that remain in the organization when employees leave (Bontis, 1998). It comprises of all non-human storehouse of knowledge in organizations including organizational competitive intelligence, routine, formula, policies, procedures and databases (Salleh and Selamat, 2007, Cabrita, 2009)

\section{Research Model and Hypothesis Development}

The proposed research model is based on three independent variables namely human capital, customer capital, structural capital and one dependent variable namely organizational performance. The research model was derived from the theoretical framework of theory of intellectual capital. This model hypothesized there is a direct and positive association between intellectual capital and organizational performance (Stewart, 1997). The relationship among the variable are depicted in the figure 1. 


\section{$<$ Insert Figure 1 here $>$}

Form the abovementioned discussion of past literature. Four research hypotheses were formulated on the bases of the conceptual research model.

\section{Hypothesis 1}

Human capital has positive association with organizational performance of SMEs

Hypothesis 2

Customer capital has positive association with organizational performance of SMEs.

Hypothesis 3

Structural capital has positive association with organizational performance of SMEs

Hypothesis 4

Intellectual capital (human capital, customer capital and structural capital) has positive impact on the organizational performance of SMEs

\section{Research Methodology and Sample Size}

A structured questionnaire based survey was conducted to collect the data from electrical and electronics SMEs operating in manufacturing sector in Gujrat and Gujranwala. The questionnaire used is an amended version of the Bontis, Nick (1998), Ismail Mazlan Bin (2005), Young et al., (2007), Tovstiga and Tulugurova (2007) and Choudhury (2010). The amendments were made to ensure the constructs is relevant to this research in Pakistani context. Kureshi et al (2010) and Fayyaz et al., (2009) argue that in Pakistan there is no complete publications about the record of the manufacturing SMEs. Therefore several sources such as Pakistan Electric Fan Manufacturing Association (2010) and Gujranwala Chamber of Commerce (2010) were used to get the data of SMEs operating in manufacturing sector and considered as reliable resources. According to these resources there were 223 registered electrical and electronics SMEs operating in manufacturing sector. Convenience sampling technique was used for data collection and 82 out of 200 questionnaires were returned from 50 SMEs in Gujranwala and Gujrat. The response rate was $41 \%$ which was quite satisfactory.

\section{Reliability of the Research Instrument}

The research assessed the construct reliability by using Cronbach Alpha value. The results showed human capital had a coefficient of 0.801, customer capital of 0.694, structural capital of .707 and organizational performance of 0.753. All of the scales were above the suggested value 0.5 (Nunnally and Bernstein, 1994; Nunnally, 1974). Therefore it was concluded that the scales used in this research were reliable.

\section{Findings}

To test the research hypotheses Pearson correlation and multiple regression was used. The result in Table 2 shows that human capital, customer capital, and structural capital has positive relationship with organizational performance. The result shows that customer capital has stronger relationship follows by structural capital. Therefore hypothesis 1 , hypothesis 2 and hypothesis 3 were accepted on the basis of empirical findings.

\section{$<$ Insert Table 2 here>}

Multiple regression analysis was used to test hypothesis 4 of the study. Namvar et al., (2010) argue that the coefficient of determination (R2) indicates the goodness of the fit of the regression model. Table 3 depicts the multiple regression results. $17.9 \%(\mathrm{R}$ square $=0.179)$ of the variance in organizational performance is jointly explained by the three independent variables $(\mathrm{F}=5.659$; $\mathrm{Sig} .=0.001)$. Therefore the research hypothesis 4 is also accepted and it concludes that the model is useful.

\section{$<$ Insert Table 3 here $>$}

The findings indicate that two variable namely customer capital and structural capital have significant impact on the organizational performance of SMEs at $95 \%$ confidence level with unstandardized beta coefficient of 0.208 $(p=0.039)$ and $0.168(p=0.049)$ respectively. However human capital shows insignificant impact on the organizational performance of SMEs at $95 \%$ confidence level with unstandardized beta coefficient $0.078(\mathrm{p}=$ $0.311)$.

\section{Discussion}

The findings of this research are consistent with previous researches. However one unexpected result shows that human capital is insignificant in regression model. The results are not surprising because the impact of intellectual capital on organizational performance can vary from organization to organizations (Bontis et al., 2000). In Pakistan most SMEs have no educated, skilled, qualified and trained employees (Fayyaz et al., 2009). This may be the major cause of this unexpected outcome for this research.

\section{Limitations and Future Study}

The study has it limitation in term of its small sample size. Therefore its applications may not be applicable for all small and medium enterprises. This study also did not cover the demographic profile of the respondents and 
organizations. Up to researchers' knowledge, this is the first study on intellectual capital that focused on SMEs in Pakistan. Therefore there is a lot of potential in this area. Future researchers could use similar hypotheses but implement the study in different form such as on a longitudinal rather than a cross-sectional study.

\section{Conclusion}

The findings of this research add to our understanding on the role of intellectual capital in electrical and electronics SMEs operating in manufacturing sector. This research has contributed to the body of knowledge and gives new direction to the entrepreneurs/managers to understand their organizational issues more swiftly. The finding of this research produced useful information about intellectual capital and its relationship with organizational performance of SMEs in Pakistani context.

\section{References}

Alam, Muhammad Masroor. (2010). Market orientation in small and medium size firms: A study on manufacturing firms in Pakistan. Pakistan Journal of Business and Management, 1(1).

Bontis, N., Keow, W. C. C., \& Richardson, S. (2000). Intellectual capital and business performance in Malaysian industries. Journal of Intellectual Capital, 1, 85-100. doi:10.1108/14691930010324188, http://dx.doi.org/10.1108/14691930010324188

Bontis, Nick. (1998). Intellectual Capital: an exploratory study that develops measures and models. Management Decision, 36(2), 63-76. doi:10.1108/00251749810204142, http://dx.doi.org/10.1108/00251749810204142

Cabrita, Maria do Rosario. (2009). Intellectual capital: a phenomenon of interrelationships. Int. J. Business and System Research, 3(2), 229-256. doi:10.1504/IJBSR.2009.024864, http://dx.doi.org/10.1504/IJBSR.2009.024864

Chen, H. M., \& Lin, K. J. (2004). The role of human capital cost in accounting. Journal of Intellectual Capital, 5(1), 116-30.

Choo, C.W \& Bontis N. (2002). The Strategic management of intellectual capital and organizational knowledge. New York, NY: Oxford University Press.

Choudhury, Jyotirmayee. (2010). Performance impact of intellectual capital: A study of Indian IT sector. International Journal of Business and Management, 5(9).

Ding, Yongliang \& Li Guanzhong. (2010). Study on the management of intellectual capital. International Journal of Business and Management, 5 (2).

Edvinsson, L., \& M. S Malone. (1997). Intellectual capital: Realizing your company's true value by finding its hidden brainpower. New York, NY: Harper Collins.

Ismail, Mazlan Bin. (2005). The Influence of intellectual capital on the performance of Telekom Malaysia: PhD Thesis. Universiti Teknologi Malaysia.

Kureshi, N. I., Mann R., Khan, M. R., \& Qureshi, M. F. (2009). Quality management practices of SME in developing countries: A survey of manufacturing SME in Pakistan. Journal of Quality and Technology Management, V(II), 63-89. doi:10.1108/17542731011035541, http://dx.doi.org/10.1108/17542731011035541

Ngah, Rohana \& Ibrahim, Abdul Razak. (2009). The Relationship of intellectual capital innovation and organizational performance: A preliminary study in Malaysian SMEs. International Journal of Management Innovation Systems, 1 (1).

Nooteboom, B. (1993). Innovation and diffusion in Small Firms: Theory and evidence. Small Business Economics, (6), 327-347.

Nunnally, J. C. (1967). Psychometric theory ( $1^{\text {st }}$ Ed.). New York, NY: McGraw-Hill.

Nunnally, J. C., \& Bernstein, I. H. (1994). Psychometric theory ( $3^{\text {rd }}$ ed.). New York, NY: McGraw-Hill, Inc.

Rohra, Chandan Lal \& Panhwar, Iqbal Ahmed. (2009). The role of SMES towards exports in Pakistan economy. Australian Journal of Basic and Applied Sciences, 3(2), 1070-1082.

Roos, G., \& Roos, J. (1997). Measuring your company's intellectual performance. Long Range Planning, 30(3), 413-426. doi:10.1016/S0024-6301(97)90260-0, http://dx.doi.org/10.1016/S0024-6301(97)90260-0

Salleh, Abdul Latif \& Selamat, Fauziah (2007). Intellectual capital management in Malaysian Public Listed Companies. International Review of Business Research Papers, 3(1), 266-278.

Shaari, Jamal Abdul Nassir, Khalique, Muhammad \& Isa, Abu Hassan bin Md. (2010). Ranking of public and domestic private sector commercial banks in Pakistan on the basis of the intellectual capital performance. Proceedings of International Borneo Business Conference (BBC2010), 1.

Small and Medium Enterprises Development Authority, Report 2001-2008. [Online] Available: www.smeda.org Stewart, T. (1997). Intellectual capital: The new wealth of organizations. New York, NY: Doubleday/ Currency. Sveiby, K. E. (1997). The new organizational wealth- managing and measuring knowledge- based assets. San Francisco, Berrett- Koehler Publisher. 
Terziovski, Mile. (2010). Research notes and commentaries innovation practice and its performance implications in small and medium enterprises (SMEs) in the manufacturing sector: A resource based view. Strategic Management Journal, 31.

Tovstiga, George \& Tulugurova, Ekaterina. (2007). Intellectual capital practices and performance in Russian enterprises. Journal of Intellectual Capital, 8(4). doi:10.1108/14691930710830846, http://dx.doi.org/10.1108/14691930710830846

United Nation Industrial Development Organization (UNIDO). Corporate Social Responsibility: implications for small \& medium enterprises in developing countries. 2002, [Online] Available: www.unido.org (October, 2006)

Wall, Anthony, Kirk, Robert \& Martin Gary. (2004). Intellectual capital measuring the immeasurable?. Jordan Hill, Oxford Linacre House: CIMA Publishing, An imprint of Elsevier.

Young, Chaur-Shiuh, Tsai, Liu-Ching \& Lee, Hung-Wen. (2007). Relationship between intellectual capital-oriented corporate performance management systems, intellectual capital and corporate performance: An exploratory study. Int. J. Accounting, Auditing and Performance Evaluation, 4(4/5), 422-442. doi:10.1504/IJAAPE.2007.017087, http://dx.doi.org/10.1504/IJAAPE.2007.017087

Yusuff Rosnah Mohd. (2004). Manufacturing best practices of the electric and electronic firms in Malaysia. Benchmarking: An International Journal, 11(4), 361-369. doi:10.1108/14635770410546764, http://dx.doi.org/10.1108/14635770410546764

Table 1. Reliability Test of Constructs

\begin{tabular}{|l|c|}
\hline Variables & Cronbach Alpha \\
\hline Human Capital & 0.801 \\
\hline Customer Capital & 0.694 \\
\hline Structural Capital & 0.707 \\
\hline Organizational Performance & 0.753 \\
\hline
\end{tabular}

Table 2. Pearson Correlation Result on the Relation between Independent Variables and Dependent Variable

\begin{tabular}{|l|c|c|c|c|}
\hline Variables & & & & \\
\hline Human Capital & 1 & & & \\
\hline Customer Capital & $.438^{* *}$ & 1 & & \\
\hline Structural Capital & $.317^{* *}$ & .170 & 1 & \\
\hline Organizational Performance & $.295^{* *}$ & $.330^{* *}$ & $.296^{* *}$ & 1 \\
\hline
\end{tabular}

Table 3. Multiple Regression Model Summary: Aggregate effect of Independent Variables on the Dependent Variable

\begin{tabular}{|l|c|c|c|}
\hline Constant & 2.112 & & \\
\hline Human Capital & 0.078 & 1.021 & 0.311 \\
\hline Customer Capital & 0.208 & 2.100 & 0.039 \\
\hline Structural Capital & 0.168 & 1.998 & 0.049 \\
\hline R & 0.423 & & \\
\hline R2 & 0.179 & & \\
\hline F Value & 5.659 & & 0.001 \\
\hline Std. Error of the Estimate & 0.46569 & & \\
\hline
\end{tabular}

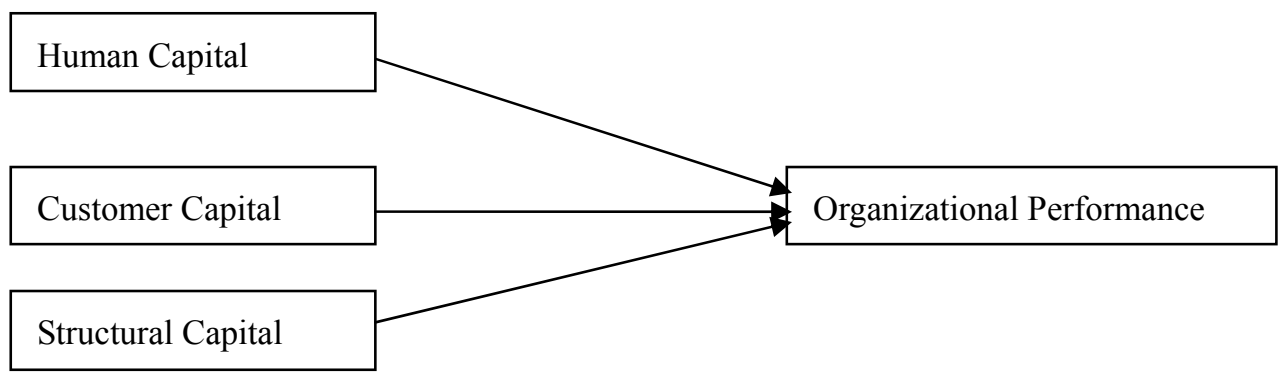

Figure 1. Theoretical Research Model 